\title{
マニピュレータの占有空間を考慮した 障害物回避動作の決定法
}

\author{
尾 崎弘 明*・毛利彰*・高 田勝* \\ Planning of Collision Free Movement of a \\ Manipulator Considering its Body Space
}

Hiroaki OzAKI*, Akira Mohri* and Masaru TAKata*

This paper formalizes the problem of moving the hand of a manipulator to the goal position and orientation avoiding the collision with obstacles in the work space and gives an algorithm to solve the formalized problem. The algorithm is given as follows: First, an efficient method of detecting the interference among links of a manipulator and obstacles is presented. Second, movable conditions of joints are shown and the problem of planning of collision free movement is formalized using these conditions. Third, an algorithm to solve the problem by the use of linear programming is given.

The obtained algorithm is applied to the planar movement of a manipulator with four links and four degrees of freedom and its effectiveness is shown.

Keyword: manipulator, interference checking, collision free movement

\section{1. ま え がき}

多関節マニピュレータの重要な機能の一つは, それ のむつ圥長な自由度を生かして, 作業域内にある障害 物を回避し，目的の動作を行えることである. 本論文 では、マニピュレータをどの部分も障害物に衝突させ るととなく，目標点（目標の位置・姿勢）まで動かす 問題を定式化し，乙れを解くアルゴリズムを提案す る.

障害物回避動作の決定問題は，つぎの二つの段階, すなわち,

（1）障害物に関する情報（形，位置，大きさ，向

* 九州大学工学部 福岡市東区箱崎 6-10-1

* Faculty of Engineering, Kyushu University, Fukuoka

(Received March 30, 1982)

(Revised May 28, 1982)
き）をどのように収集し，また，これを用いて障害物 をどのように記述するか。

（2）障害物は記述されているとして，各関節をど のように動かせば障害物を回避して目標点に到達でき るか.

に分けられる.

（1）に関しては，未知環境のマップの自動作成に関 する研究1)や, 人間と計算機との対話によって環境を 記述する研究2)などが行われ，効果的なマニピニレー 夕作業域の記述の問題が取り扱われている. この記述 が完了すると, 障害物回避動作の決定問題は，（2)の 問題になる.

(2)の問題の解決法として, マニピュレータを直線 および幾つかの代表点として取り披う方法が提案され

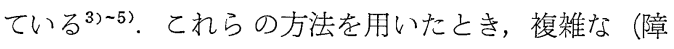
害物が入り組んでいる）作業域では，考慮に入れた直 線および代表点以外の部分が，障害物に衝突してしま う可能性がある. 一方, マニピュレータの占有空間を 考慮に入れた解決法む提案されている(6) -9). Kulakov は，マニピュレータの各リンクを，乙れを内包する面 方体で表わし，乙れらが障害物に侵入しない条件を考 えた6). しかし, ての方法では, 障害物形状の限定や, 腕全体を被う触覚センサの利用を前提とするなどの制

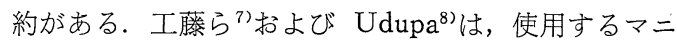
ピュレータ構造の特長を利用した解決法をそれぞれ提 案した. ところが，これらの方法は一般化が困難であ り，また複雑な作業域での問題には適用しにくい. Lozano-Pérez は,多面体で表わされる物体が, 多面体 の障害物が置かれている領域を, 姿勢を変えずに目標 位置まで移動するとき, 最短径路が容易に見い出せる ことを示した ${ }^{10)}$. そこで，彼はこの特長を利用して， マニピュレータの障害物回避問題の解決を試みた ${ }^{91}$.

しかし，回転自由度をむつマニピュレータでは，乙の 
方法によっで最短径路を見い出すととは現実的に不可 能であり，また，回䎐自由度が多くなると，目標点に 到達可能な径路の選定も複雑で困難なものになる．こ のため，多自由度のマニピュータを用いる場合には， 大幅な近似が必要となり, その結果, 目標点まで到達 しうる径路が見落されてしまう，以上に述べたよう に, 現在までに提案されている方法は, 一般の多自由 度多リンクマニピュレータの障害物回避動作の決定に 適しているとは言い難い，以下では，乙の動作決定問 題のより有効な解法を検討する.

本論文では，つぎのような二つの前提の屯とに，障 害物回避問題を取り扱う。つまり，

（1）マニピニレータの各リンク（把握された物 体，すなわち，ワークまたは工具などむ一つのリンク と見なす）および障害物は，直方体またはその組合せ で表現できる.

（2）マニピュレータの手先（およびワークなど, 以下ではワークとのみいう）の径路（厳密に満足させ る必要はない推定径路）の候補（注1）が与えられる.

（1）は，リンクや障害物の記述を容易にするため と, これらの互いの干渉（接触または侵入）を見い出 すのに要する演算を少なくするための前提である. 記 述の精度を高める必要があれば，おのおののリンクお よび障害物を幾つかの直方体の組合せで表現すればよ い. 障害物が記述されると，ワークのみが通過できる 径路は比較的容易に得られるので, 前提 $(2)$ は妥当と 思われる。

以上の前提のもとに，障害物回避動作の決定問題を できるだけ一般的に定式化する．乙の定式化には，マ ニピュレータと障害物との接触点の検出が不可欠であ るから，乙の効果的な検出法を提案する.さらに，乙 れを用いて, 定式化した問題を解くアルゴリズムを与 える. また, 平面運動の例にこのアルゴリズムを適用 し, シミュレーションを行い, 提案する動作決定法の 有効性を示す.

\section{2. 接触検出と関節の可動条件}

マニピュレータの障害物回避動作を決定するには, 関節の動きが与えられたとき, マニピュレータが障害 物と干渉する部分を見い出さねばならない.

ての干渉部分を見い出す方法として，（1）マニピュ レータの作業域をあらかじめ定めた大きさのブロック に分割し，障害物が占める空間ブロックとマニピュレ

(注1) 以下では, 径路の候補とは, 目標点に至るワーク の推定された中間指定点（中間目標の位置・姿勢） の軌道を意味する.

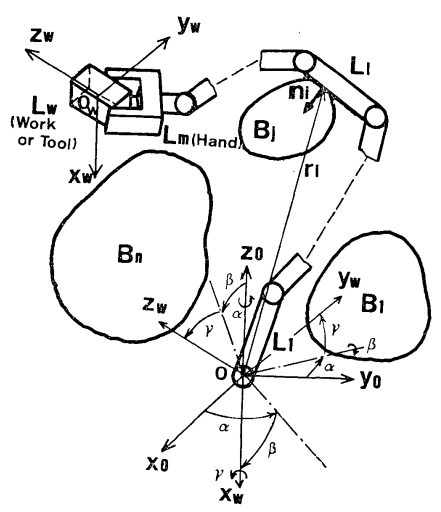

Fig. 1 Manipulator movement in the presence of obstacles

ータが占める空間ブロックとの共通ブロックを見い出 して干步を求める方法，（2）障害物およびマニピュレ 一夕の占有空間を定める面や棱を数式表現し，乙れら の交点を求めることによって干渉部分を見い出す方 法 ${ }^{11}$ がある，前者は，干渉部分を精度よく求めるには 多くの記憶容量が必要になる.また, 後者では, 面や 棱を表わす式を一つ一つ組合せて交点の有無を調べね ばならず，干渉部分を見い出すには多くの演算が必要 である.

ここでは, 接触点を効率よく見い出すために, マニ ピュレータの各リンクを表わす直方体と, 障害物を表 わす直方体とが接触するための必要条件を求める。 ま た，乙の条件を繰返して適用すれば，接触点が必要な 精度で得られることを示す.ささらに, 得られた接触点 を用いて関節の可動条件を求める.

\section{1 リンクと障害物の表現}

いま，Fig. 1 亿示すように，m個のリンク $L_{1} \sim L_{m}$ (ただし， $L_{m}$ は手先）からなるマニピュレータが， ワ 一ク $L_{w}$ をむち, $n$ 個の障害物 $B_{1} \sim B_{n}$ が存在する作 業域内を動くとする.リンクおよび障害物は, 実際に は種々の形状をとるが，1章の前提 (1) 亿従い直方体 またはその組合せで表わされる。しかし, 以下では議

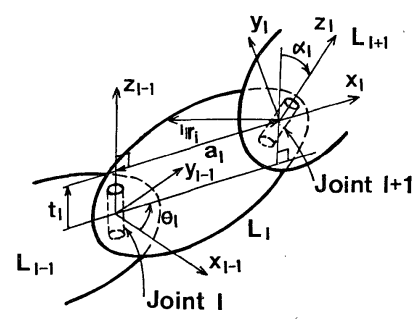

Fig. 2 Coordinate axes definitions for two adjacent links and relationships between the two coordinate axes 
論を簡単にするために，各リンクおよび障害物をそれ ぞれこれを内包する1つの直方体で表わし，乙れらを 改めてリンク $L_{l}(l=1, \cdots, m$, w) および障害ブロック $B_{j}(j=1, \cdots, n)$ と呼ぶ.

マニピュレータの運動を記述するために, Denavit ら ${ }^{12)}$ の表現を用いて，リンクに固定された座標系を導 入する.関節 $l$ はンク $L_{l-1}$ とリンク $L_{l}$ とを繫ぐ 関節としよう。とのとき, リンク $L_{l}$ に固定された 座標系 $O_{l}-x_{l} y_{l} z_{l}$ をつぎのように定める (Fig. 2参 照).

$z_{l}:$ 関節 $l+1$ の軸にそう力向.

$x_{l}: z_{l-1}$ 加ら $z_{l}$ に向汃，乙れらの共通垂線を なす方向

$y_{l}: o_{l}-x_{l} y_{l} z_{l}$ が右手系をなす方向.

この表現を用いると，l座標系においてその原点か らみたリンク $L_{l}$ 内の点 $i^{\prime}{ }^{l} \boldsymbol{r}_{i}=\left({ }^{l} x_{i}{ }^{l} y_{i}{ }^{l} z_{i}\right)^{T}$ は, $l-1$ 座標系で表わすと，

$\left[\begin{array}{c}l-1 \\ \boldsymbol{r}_{i}\end{array}\right]={ }^{l-1} A_{l}\left[\begin{array}{c}l \\ \boldsymbol{r}_{i} \\ 1\end{array}\right]$

となる．乙のとき，座標変換マトリクス ${ }^{l-1} A_{l}$ は，

$$
{ }^{-1} A_{l}=\left[\begin{array}{rrr:r}
c_{l} & -s_{l} c_{\alpha l} & s_{l} s_{\alpha l} & a_{l} c_{l} \\
s_{l} & c_{l} c_{\alpha l} & -c_{l} s_{\alpha l} & a_{l} s_{l} \\
0 & s_{\alpha l} & c_{\alpha l} & t_{l} \\
\hdashline 0 & 0 & 0 & 1
\end{array}\right]
$$

である. ここに, $s_{l}=\sin \theta_{l}, \quad c_{l}=\cos \theta_{l}, \quad s_{\alpha l}=\sin \alpha_{l}$ お よび $c_{\alpha l}=\cos \alpha_{l}, a_{l}, \alpha_{l}, \theta_{l}, t_{l}$ は Fig. 2 で与えら れている，lが回転の自由度をむつ関節であれば, $\theta_{l}$ が変数，直進移動をする関節ならば $t_{l}$ が変数となる。 この関係を用いてリンク $L_{l}$ 内の点 $i$ をベース座標系 （０座標系）で表わせば，つぎのようになる.

$$
\left[\begin{array}{c}
\boldsymbol{r}_{i} \\
1
\end{array}\right]={ }^{0} A_{1}{ }^{1} A_{2} \cdots^{l-1} A_{l}\left[\begin{array}{c}
l \\
\boldsymbol{r}_{i} \\
1
\end{array}\right]={ }^{0} A^{l}\left[\begin{array}{c}
l \boldsymbol{r}_{i} \\
1
\end{array}\right]
$$

一方，障害ブロック $B_{j}$ についてむ，乙れに固定さ れた座標系 $\bar{o}_{j}-\bar{x}_{j} \bar{y}_{j} \bar{z}_{j}$ (以下 $B_{j}$ 座標系と呼引゙）を導

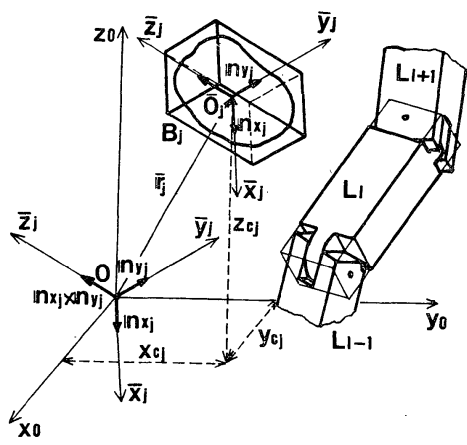

Fig. 3 Description of obstacle $B_{j}$ with respect to base coordinates

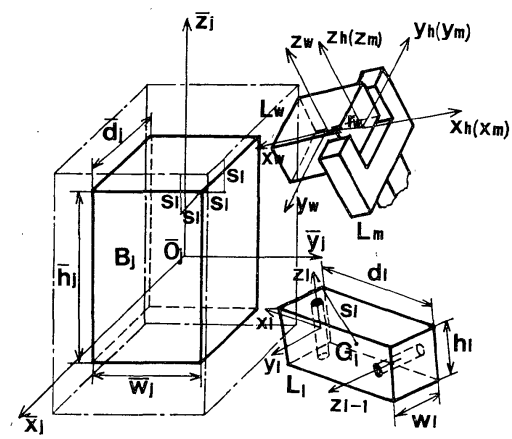

Fig. 4 Relationship between obstacle $B_{j}$ and link $L_{l}$ with respect to $B_{j}$ coordinates

入する.すなわち，Fig. 3 に示すように， $B_{j}$ の重心 を原点とし，直方体の各稜と平行に $\bar{x}_{j}, \bar{y}_{j}$ および $\bar{z}_{j}$ 軸をとる．ベース座標系原点からみた $\bar{o}_{j}$ の位置を $\overline{\boldsymbol{r}}_{j}$ $=\left(\bar{x}_{j} \bar{y}_{j} \bar{z}_{j}\right)^{T}$ とし， $\bar{x}_{j}$ 軸および $\bar{y}_{j}$ 軸のベース座標系 に対する方向余弦をそれぞれ $\boldsymbol{n}_{x j}, \boldsymbol{n}_{y j}$ とすれば, $B_{j}$ 座 標系からベース座標系への変換マトリクス ${ }^{0} \bar{A}_{j}$ は，

$$
{ }^{0} \bar{A}_{j}=\left[\begin{array}{ccc:c}
\boldsymbol{n}_{x j} & \boldsymbol{n}_{y j}\left(\boldsymbol{n}_{x y} \times \boldsymbol{n}_{y j}\right) & \overline{\boldsymbol{r}}_{j} \\
\hdashline 0 & 0 & 0 & 1
\end{array}\right]
$$

で表わせる.

\section{2 接触検出}

本節ではリンクと障害ブロックとの干渉の必要条件 を導き，乙れを用いた接触点検出法を述べる．以下に おいて，リンク $L_{l}$ と障害ブロック $B_{j}$ との接触を例 として説明する。

$L_{l}$ 内の点 $i$ は，(4)式を用いると' $B_{j}$ 座標系の原 点を基準にして表わすととができ，

$$
\left[\begin{array}{c}
j \boldsymbol{r}_{l i} \\
1
\end{array}\right]=\left(\begin{array}{lll}
0 & \bar{A}_{j}
\end{array}\right)^{-1}{ }^{0} A_{l}\left[\begin{array}{c}
l \boldsymbol{r}_{i} \\
1
\end{array}\right]
$$

となる，乙の関係は， $B_{j}$ 座標系を基準にして $L_{l}$ を 見たととを示し，Fig. 4 のように表現できる。この 関係を用いれば， $L_{l}$ が $B_{j}$ と干渉するための必要条 件は以下のように得られる。

$l$ 座標系からみた $L_{l}$ の重心 ${ }^{l} \boldsymbol{r}_{G}$ は, $B_{j}$ 座標系から みると,

$$
\left[\begin{array}{c}
\boldsymbol{r}_{l G} \\
1
\end{array}\right] \equiv\left(\begin{array}{llll}
{ }^{j} x_{l G} & { }^{j} y_{l G}{ }^{j} z_{l G} & 1
\end{array}\right)^{T}=\left(\begin{array}{lll} 
& & \bar{A}_{j}
\end{array}\right)^{-1}{ }^{0} A_{l}\left[\begin{array}{c}
l \\
\boldsymbol{r}_{G} \\
1
\end{array}\right]
$$

となる． $L_{l}$ と $B_{j}$ の大きさを，Fig. 4 亿示すよう に，それぞれ $\left(d_{l}, w_{l}, h_{l}\right),\left(\bar{d}_{j}, \bar{\varpi}_{j}, \bar{h}_{j}\right)$ を用いて表わ す.乙のとき， $L_{l}$ の重心とその頂点間の距離は,

$$
s_{l}=\frac{1}{2} \sqrt{d_{l}^{2}+w_{l}^{2}+h_{l}^{2}}
$$

となる，乙れらの值を用いると，つぎの 3 条件 


$$
\left|{ }^{j} x_{l G}\right| \leq \frac{\bar{d}_{j}}{2}+s_{l},\left|{ }^{j} y_{l G}\right| \leq \frac{\bar{w}_{j}}{2}+s_{l},\left|{ }^{j} z_{l G}\right| \leq \frac{\bar{h}_{j}}{2}+s_{l}
$$

を同時に満たすととが， $L_{l}$ が $B_{j}$ と干渉するための 必要条件となる。したがって，いずれか一つでも満足 しなければ接触の可能性はない.

いま，(8)式が満たされているとしよう。このと き， $L_{l}$ をさらに細分化した小ブロックそれぞれにつ いて，同様な判定を行えば， $L_{l}$ のどの部分が $B_{j}$ と 干渉するかを知るととができる，たとえば， $L_{l}$ を大 きさ $\left(d_{l} / 2, w_{l} / 2, h_{l} / 2\right)$ のつのブロックに等分割する 場合を考えよう。乙の分割ブロックそれぞれについて （8）の条件を調べ，干渉の可能性のあるあののみを再 び $1 / 8$ に等分割する．以下この手順を繰返したとき，

$L_{l}$ の $1 / 8^{p-1}$ (pは正の整数) の大きさの小ブロック が $B_{j}$ と干渉するための必要条件は，乙のブロック重 心を ${ }^{j} \boldsymbol{r}_{l G} \underbrace{\ldots \ldots}_{p-1}=({ }^{j} x_{l G} \underbrace{\ldots \ldots}_{p-1}{ }^{j} y_{l G} \underbrace{\ldots \ldots}_{p-1}{ }^{j} z_{l G \ldots \ldots . . .})^{T}$ で表わす とき，

$$
\begin{aligned}
& |{ }^{j} x_{l G} \underbrace{\cdots \cdots}_{p-1}| \leq \frac{\bar{d}_{j}}{2}+s_{l p-1}, \quad|{ }^{j} y_{l G} \underbrace{\cdots \cdots}_{p-1}| \leq \frac{\bar{w}_{j}}{2}+s_{l p-1} \\
& |{ }^{j} z_{l G} \underbrace{\cdots \cdots}_{p-1}| \leq \frac{\bar{h}_{j}}{2}+s_{l p-1} \quad \text { ここに } s_{l p-1}=s_{l} / 2^{p-1}
\end{aligned}
$$

となる。

ここで，（9)式を満たす ${ }^{j} \boldsymbol{r}_{l G} \underbrace{\ldots \ldots . . .}_{p-1}$ に重心をむつ小ブ ロックについて考える．乙の小ブロックをさらに $1 / 8$ に分割したブロック（すなわち， $L_{l}$ の $1 / 8^{p}$ の大きさ のブロック)の重心を ${ }^{j} \boldsymbol{r}_{l G} \underbrace{\ldots \ldots i}_{p-1}=({ }^{j} x_{l G} \underbrace{\ldots \ldots i}_{p-1}{ }^{j} y_{l G} \underbrace{\ldots \ldots}_{p-1}$ ${ }^{j} z_{l G} \underbrace{\cdots \ldots i}_{p-1})^{T}(i=1, \cdots, 8)$ で表わす．乙のとき,つきの 3 条件

$$
\begin{aligned}
& |{ }^{j} x_{l} \underbrace{\cdots \cdots i}_{p-1} i| \leq \frac{\bar{d}_{j}}{2}, \quad|{ }^{j} y_{l G} \underbrace{\cdots \cdots i}_{p-1} i| \leq \frac{\bar{\varpi}_{j}}{2}, \\
& |{ }^{j} z_{l G} \underbrace{\cdots \cdots i}_{p-1} i| \leq \frac{\bar{h}_{j}}{2}
\end{aligned}
$$

を同時に満たす分割ブロック $i$ は， $B_{j}$ と干渉してい ๖.

以上に述べた方法により，pを適当にとれば，マニ ピュレータの各リンクが障害ブロックと干渉する部位 を必要な精度で求めることができる．ただし，障害物 回避動作を求めるには，リンクが障害ブロックに侵入 する以前に接触を検出できなければならない，このた め, 各リンクの外側に余分な領域を付加し，乙の領域 内で障害ブロックと干渉する部分を求め，乙の重心を 接触点とみなす。

\section{3 関節の可動条件}

マニピュレータの関節の動きの現在值が与えられ， 接触点が前節の方法によって得られたとき，各リンク を障害ブロックに侵入させない関節の動きを考える.

いま, Fig. 1 に示すように, リンク $L_{l}$ 上の点 $i$ $(i=1, \cdots, q ; q$ はリンクと障害ブロックとの接触点 数）で障害ブロック $B_{j}$ と接するとする．また，ベー ス座標系原点からこの接触点までの距離を $\boldsymbol{r}_{i}$ とする。 $B_{j}$ の占有空間が,

$$
h_{j}(\boldsymbol{r}) \leq 0
$$

で表わされるとする， $\boldsymbol{r}_{i}$ は $B_{j}$ の境界上にあるから，

$$
h_{j}\left(\boldsymbol{r}_{i}\right)=0
$$

そこで，マニピュレータの関節が微小量 $\delta \boldsymbol{\theta}=\left(\delta \theta_{1} \cdots\right.$ $\left.\delta \theta_{m}\right)^{T}$ (注2) だけ動いた結果， $L_{l}$ 上の点 $i$ は $\delta \boldsymbol{r}_{i}$ だけ 動くとしよう。このとき， $\boldsymbol{r}_{i}+\delta \boldsymbol{r}_{i}$ は $B_{j}$ (境界を除 く）内に入ってはならないから，

$$
h_{j}\left(\boldsymbol{r}_{i}+\delta \boldsymbol{r}_{i}\right) \geq 0
$$

を満たさなければならない，乙の条件は， $\delta \boldsymbol{r}_{i} の 2$ 次 以上の項を無視すると，

$$
\partial h_{j} / \partial \boldsymbol{r} \mid \boldsymbol{r}=\boldsymbol{r}_{i} \cdot \delta \boldsymbol{r}_{i} \geq 0
$$

となる. $\partial h_{i} / \partial \boldsymbol{r} \mid \boldsymbol{r}=r_{i}$ は, 点 $i$ においてブロック $B_{j}$ の 内側に向かう法線方向の単位ベクトル $\boldsymbol{n}_{i}$ と逆符号を あち，乙れに比例するから，(14)式は結局，

$$
\boldsymbol{n}_{i} \cdot \delta \boldsymbol{r}_{i} \leq 0
$$

となる。

一方, $l$ 座標系原点からみた点 $i$ の位置 ${ }^{l} \boldsymbol{r}_{i}$ を用い て $\boldsymbol{r}_{i}$ を表現すると，

$$
\left[\begin{array}{c}
\boldsymbol{r}_{i} \\
1
\end{array}\right]={ }^{0} A_{l}\left[\begin{array}{c}
l \boldsymbol{r}_{i} \\
1
\end{array}\right]
$$

である.乙の関係より，各関節が $\delta \theta_{j}(j=1, \cdots, l)$ だけ 動いたときの点 $i の$ 動きはつぎのようになる.

$$
\left[\begin{array}{c}
\delta \boldsymbol{r}_{i} \\
0
\end{array}\right]=\sum_{j=1}^{l} U_{l j} \delta \theta_{j}\left[\begin{array}{c}
l \\
\boldsymbol{r}_{i} \\
1
\end{array}\right]
$$

ここに, $U_{l j}={ }^{0} A_{1}{ }^{1} A_{2} \ldots \ldots{ }^{j-2} A_{j-1} Q_{j}^{j-1} A_{j} \ldots \ldots{ }^{l-2} A_{l-1}$ ${ }^{l-1} A_{l} ， \quad Q_{j}$ は $\partial^{j-1} A_{j} / \partial \theta_{j}=Q^{j-1} A_{j}$ を満たす定数マ トリクス.

以上により，関節の可動条件は，(15)式および (17) 式を用いて表わせる。

\section{3. 障害物回避動作決定問題の定式化}

本章では，前節で導びかれた関節の可動条件をもと に，障害物回避動作の決定問題を定式化する.ここで 扱う問題では，1章で述べたように，マニピュレータ のワークの中間目標位置・姿勢の軌道が与えられてい

(注 2) とてでは, 回転運動, 直進移動とむに $\theta_{i}(i=1$, m) で表わす. 
るとする，姿勢の軌道は，作業内容に応じて姿勢が指 定されていれば，その指定值をとるように与えられ， 指定がなければ，中間目標位置の軌道を通る際，ワー クが障害物に衝突しないように与えられるすのとす る.

\section{1 目的関 数}

ここでは，ワークの動きが，与えられた径路の候補 のできるだけ近傍を通るようにする，そこで，目標点 に至るまでの動きを $K$ ステップに分け， $k(k=1, \cdots$, $K)$ ステップでの目的関数をつぎのように定める.す なわち。

$$
f_{k}=\left\|\left(\boldsymbol{r}_{w}{ }^{k}-\boldsymbol{r}_{w}\right) / s_{t}\right\|^{2}+C\left\|\left(\boldsymbol{a}_{w}{ }^{k}-\boldsymbol{a}_{w}\right) / a_{t}\right\|^{2}
$$

ここに, $\boldsymbol{r}_{w}{ }^{k}, \boldsymbol{a}_{w}{ }^{k}: k$ ステップのワークの目標位置お よび姿勢, $s_{t}$ : マニピュレータの長さ， $a_{t}$ : 最大姿勢 角 $\left(a_{t}=\max _{\substack{1 \leqq k \leqq K \\ 1 \leqq e \leqq E}}\left|\left(\boldsymbol{a}_{w}{ }^{k}\right)_{e}\right|\right.$ ，ただし $\left(\boldsymbol{a}_{w}{ }^{k}\right)_{e}, E$ はそれぞれ $\boldsymbol{a}_{w}{ }^{k}$ の第 $e$ 成分およびその成分数を示す). C : 位置に 対する姿勢の重み, $\boldsymbol{r}_{w}, \boldsymbol{a}_{w}$ : 現在のワークの位置およ び姿勢.

ワークの位置 $\boldsymbol{r}_{w}$ はつぎの関係より得られる.

$$
\begin{aligned}
{\left[\begin{array}{c}
\boldsymbol{r}_{w} \\
1
\end{array}\right] } & ={ }^{0} A_{m}{ }^{m} A_{w}\left[\begin{array}{l}
\mathbf{0} \\
1
\end{array}\right] \\
& =\left[\begin{array}{c:c:c}
{ }^{0} R_{m} & \boldsymbol{r}_{m} \\
\hdashline \mathbf{0} & 1
\end{array}\right]\left[\begin{array}{c:c}
{ }^{m} R_{w} \boldsymbol{r}_{w} \\
\hdashline \mathbf{0} & 1
\end{array}\right]\left[\begin{array}{l}
\mathbf{0} \\
1
\end{array}\right] \\
& =\left[\begin{array}{c}
\boldsymbol{r}_{m}+{ }^{0} R_{m}{ }^{m} \boldsymbol{r}_{w} \\
1
\end{array}\right]
\end{aligned}
$$

ここに, ${ }^{0} R_{m},{ }^{m} R_{w}:$ それぞれ手先座標系からベース 座標系，ワーク座標系から手先座標系への回転マトリ クス, $\boldsymbol{r}_{m},{ }^{m} \boldsymbol{r}_{w}$ : それぞれベース座標系原点から手先 座標系原点, 手先座標系原点加らワーク座標系原点ま での距離を表わすべクトル．

姿勢 $\boldsymbol{a}_{w}$ は,たとえば，Fig. 1 のような姿勢角 $\alpha, \beta$, $\gamma$ を用いると，回転マトリクスとつぎの関係にある。

$$
\begin{aligned}
& { }^{0} R_{w} \triangleq 0 R_{m}{ }^{m} R_{w} \\
& =\left[\begin{array}{ccc}
c_{\alpha} c_{\beta} & -s_{\alpha} c_{\gamma}+c_{\alpha} s_{\beta} s_{\gamma} & s_{\alpha} s_{\gamma}+c_{\alpha} s_{\beta} c_{\gamma} \\
s_{\alpha} c_{\beta} & c_{\alpha} c_{\gamma}+s_{\alpha} s_{\beta} s_{\gamma} & -c_{\alpha} s_{\gamma}+s_{\alpha} s_{\beta} c_{\gamma} \\
-s_{\beta} & c_{\beta} s_{\gamma} & c_{\beta} c_{\gamma}
\end{array}\right]
\end{aligned}
$$

ここに, $c_{\alpha}=\cos \alpha, s_{\alpha}=\sin \alpha$ など.

したがって， ${ }^{0} R_{w}$ の $i$ 行 $j$ 列の要素を $R_{l j}$ と表わせ ば，姿勢 $\boldsymbol{a}_{w}$ はつぎのようになる.

$$
\boldsymbol{a}_{w}=\left[\begin{array}{c}
\alpha \\
\beta \\
\gamma
\end{array}\right]=\left[\begin{array}{l}
\tan ^{-1}\left(R_{21} / R_{11}\right) \\
\sin ^{-1}\left(-R_{31}\right) \\
\tan ^{-1}\left(R_{32} / R_{33}\right)
\end{array}\right]
$$

\section{2 制約条件}

目的関数(18)式を最小にするように各関節の動きを 決めるとき，以下の二つの型の制約条件を考慮に入れ なければならない。一つは，マニピュレータの構造上
の制約による関節の可動範囲の制限であり，つぎの形 で与えられる。

$$
\theta_{j \min } \leq \theta_{j} \leq \theta_{j \max } \quad(j=1, \cdots, m)
$$

ここに， $\theta_{j \min }, \theta_{j \max }$ はそれぞれ関節の最小および最 大関節角. むう一つは，リンクが障害ブロックに接し たときに課せられる関節の可動条件であり，2 章 3 節 で導かれたように，

$$
\boldsymbol{n}_{i} \cdot \delta \boldsymbol{r}_{i} \leq 0 \quad(i=1, \cdots, q)
$$

で与えられる。

\section{4. 動作決定のアルゴリズム}

前章で定式化された問題を解くアルゴリズムについ て述べる.アルゴリズムの流れは，リンクが障害ブロ ックに接触するか否かによって分かれる.

（1）接触条件がある場合 目的関数 $f_{k}$ を $k$ ステ ップの $i-1$ サブステップで得られた関節角 $\theta_{i-1}{ }^{k}$ の 周りで線形化する. そして， $\delta \boldsymbol{\theta}$ 亿対する $f_{k}$ の変化分 をあらたに $k$ ステップの $i$ サブステップでの目的関数 と考える。すなわち、

$$
\delta f_{i}{ }^{k}=\partial f_{k} /\left.\partial \boldsymbol{\theta}\right|_{\boldsymbol{\theta}_{i-1}{ }^{k}} \cdot \delta \boldsymbol{\theta}
$$

(22)，(23)式は線形の制約条件であるから，i サブス

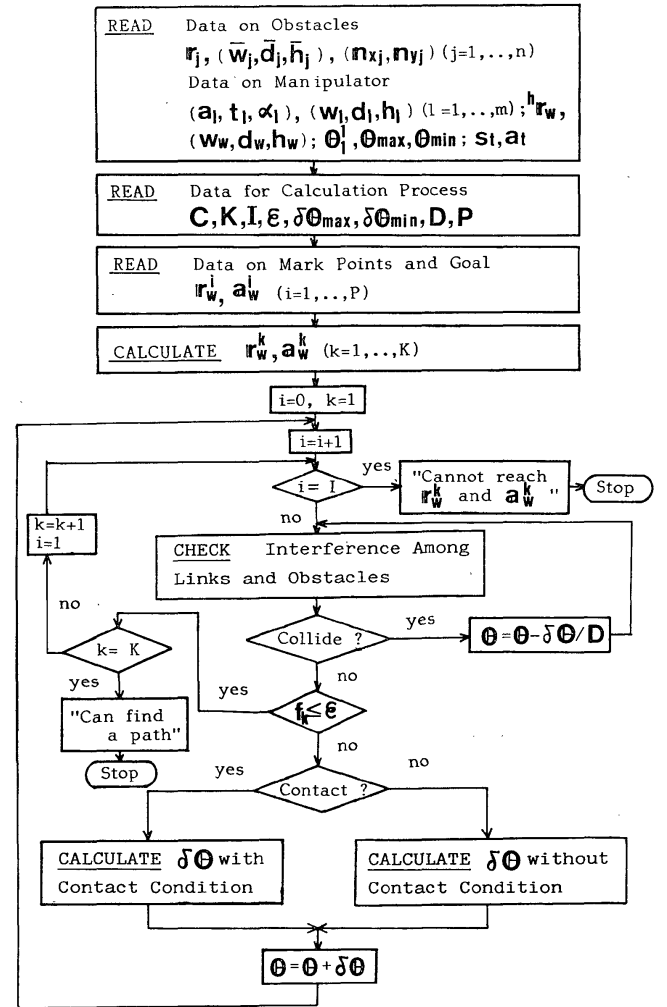

Fig. 5 Flow chart of planning of collision free movement 
テップの関節角增分 $\delta \theta_{i}{ }^{k}$ は, 線形計画法を用いて求 められる. この結果, $k$ ステップの $i$ サブステップで の関節の動きはつぎのようになる.

$$
\boldsymbol{\theta}_{i}^{k}=\boldsymbol{\theta}_{i-1}{ }^{k}+\delta \boldsymbol{\theta}_{i}{ }^{k}
$$

ただし， $\delta f_{i}{ }^{k}$ が線形化した目的関数として意味をも つためには，つぎの条件

$$
\delta \theta_{j \min } \leq \delta \theta_{j} \leq \delta \theta_{j \max } \quad(j=1, \cdots, m)
$$

を追加しておく必要がある。

（2）接触条件がない場合 制約条件 (23)を除いて （1）と同様な解法が使える，しかし，乙の場合には， 関節 $m$ から関節 1 亿向かって順に制約条件を満たす範 囲で各関節を動かし，目的関数 $f_{k}$ が小さくなるよう に $\theta_{i}{ }^{k}$ を求めるととむできる，5章の例では後者の方 法を用いる.

以上により，動作決定の手順は Fig. 5 に示す流れ 四のようになる，およその手順は以下のとおり.

(1) 障害物に関するデータの読込み.

（2）計算過程で必要なデータの読込み.

（3）目標点执よび指定点の読込み，

(4) $k$ ステップの目標点の算出(注 3 ).

(5) $k=1, i=1$ と置く.

(6) $k$ ステップのサブステップ $i$ で $\theta_{i}{ }^{k}$ を以下の 手順で求める.

(i) $i=I$ ( $I$ は (2) で指定される整数) なら， $k$ ステップの目標点に到達できないとみなし， $\theta_{i}{ }^{k}$ の決定を打切る. $i<I$ なら (ii)へ.

(ii) $\theta_{i-1}{ }^{k}$ でリンクと障害物とが干渉しているか 否かを調べる，侵入していれば $\theta_{i-1}{ }^{k}=\theta_{i-1}{ }^{k}$ $-\delta \theta_{i-1}{ }^{k} / D$ (Dは（2)で指定される定数）と し，再び干渉のチェック，侵入していなけれ ば(iii)へ.

(iii） $\theta_{i-1}{ }^{k}$ で $k$ ステップの目標点に到達している か否かを調べる。すなわち， $f_{k}$ を計算し $f_{k}$ $\leq \varepsilon （ \varepsilon は(2)$ で指定される定数）なら（iv） へ. $f_{k}>\varepsilon$ ならば $(\mathrm{v})$ へ.

(iv) $k=K$ なら動作決定終了. $k<K$ なら $k=k$ $+1, \quad i=1$ と置き $(\mathrm{i})$ 亿.

（v）接触, 非接触それぞれの場合に応じて $\delta \theta_{i}{ }^{k}$ を 求め $\theta_{i}{ }^{k}$ を得る. $i=i+1$ と置き $(i)$.

（6）（i ）で動作決定が打切られた場合には，別の候 補径路に従って動作決定を行う。乙の場合には，（3） に戻る。

(注 3 ) (1)，(3)が行われたとき，(4)が行えるととが 前提である。

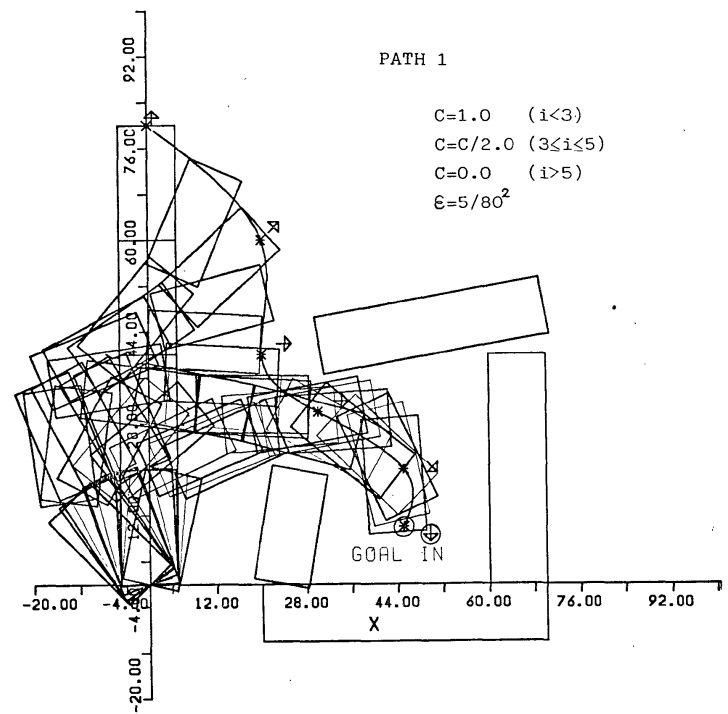

(a) Successive manipulator movement

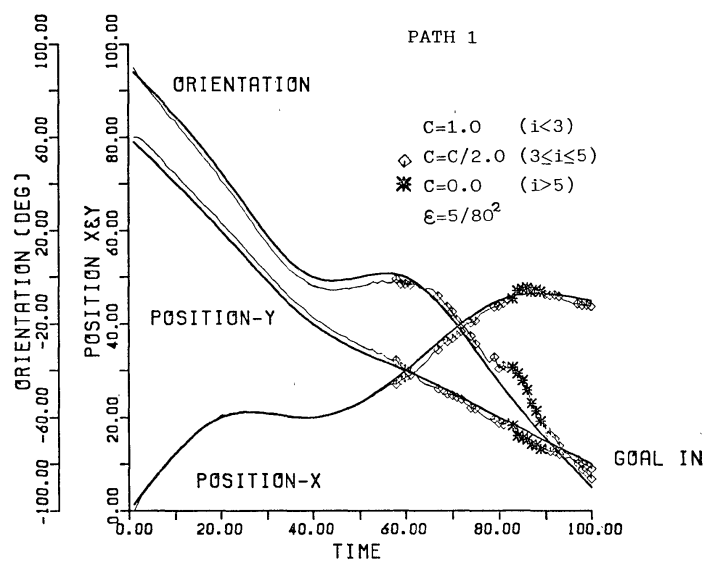

(b) Assumed and planned paths of position and orientation

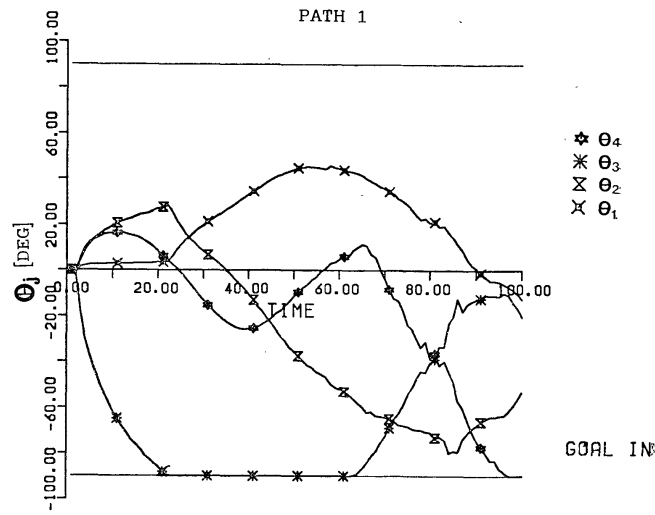

(c) Planned joint movements

Fig. 6 Planned collision free movement Example 1 


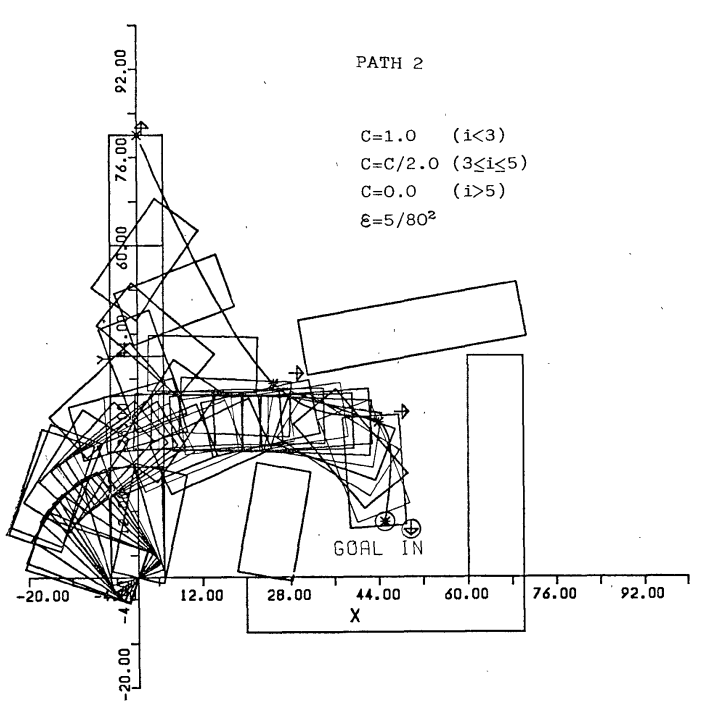

Fig. 7 Planned collision free movement Example 2 Successive manipulator movement

\section{5. シミュレーション例}

平面運動をする 4 自由度 4 リンクのマニピュレータ の動作決定に提案したアルゴリズムを適用し，このア ルゴリズムの有効性を確認する.

Fig. 6(a) および Fig. 7 亿示すように，作業域に は 4 個の障害ブロックが置がれている. マニピュレー タは，てれらを避けながら， $L_{4}$ 先端の位置と $L_{4}$ の姿 勢とが目標の位置 $\circledast$ と姿勢(Dになるように動かされ る. 目標点到達のステップは $K=100$ とし, Fig. 6 で は $k=20,40,60,80$ で 4 個の指定点を与え, Fig. 7 で は $k=33,67$ において 2 個の指定点を与えている. 径 路の候補には，乙れらの指定点を通るスプライン曲線 (Fig. 6(a)，(b)，Fig. 7 の実線）を用いた.シミュ レーションに用いた主なデータは以下のとおり.

$$
\begin{aligned}
& \left(d_{l}, w_{l}\right)=(20.0 .10 .0) \quad(l=1, \cdots, 4): \\
& { }^{0} A_{1}=\left[\begin{array}{ccc}
-\sin \theta_{1} & -\cos \theta_{1} & -20.0 \sin \theta_{1} \\
\cos \theta_{1} & -\sin \theta_{1} & 20.0 \cos \theta_{1} \\
0 & 0 & 1
\end{array}\right], \\
& { }^{l-1} A_{l}=\left[\begin{array}{ccc}
\cos \theta_{l} & -\sin \theta_{l} & 20.0 \cos \theta_{l} \\
\sin \theta_{l} & \cos \theta_{l} & 20.0 \sin \theta_{l} \\
0 & 0 & 1
\end{array}\right] \text {; } \\
& (l=2,3,4)
\end{aligned}
$$

$\theta_{j \max }=-\theta_{j \min }=90(\operatorname{deg})(j=1, \cdots, 4) ; \delta \theta_{1_{\max }}=-\delta \theta_{1_{\min }}$ $=0.5(\mathrm{deg}), \quad \delta \theta_{2 \max }=-\delta \theta_{2 \min }=1.0(\mathrm{deg}), \quad \delta \theta_{3 \max }=-$ $\delta \theta_{3 \min }=1.5(\mathrm{deg}), \quad \delta \theta_{4 \max }=-\delta \theta_{4 \min }=2.0(\mathrm{deg}) ; \quad C=$ $1.0 ; \varepsilon=5 / 80^{2}$ :

Fig. 6(a) および Fig. 7 は，10ステップでとのマ
第 18 巻 第 9 号

ニピュレータの位置を示している，乙れらの位置は， 障害ブロックに衝突せずに与えられた候補径路を実現 している.ただし，Fig. 7 では $k=20$ の近傍では $f_{k}$ を小さくするてとが困難であるため， $f_{k}$ が $\varepsilon$ 以下にならなくても動作決定を続行させている，ての 例では $k=30$ までの関節の動きの変化が大きい．との ように, 径路の与方が動作決定に与える影響は大き い. Fig. 6(b)，（c）は，100ステップを目標点汇到達 するまでの所要時間とるなし，与えられた位置・姿勢 軌道と決定された位置・姿勢軌道との関係, 得られた 各関節の動きをそれぞれ図示している，上記の 2 例で は，位置と姿勢とに等しい重みをつけたので，途中の ステップで位置と姿勢とを共に与えられた軌道汇合せ ている. ての場合, 径路の与え方によっては次ステッ プに進めないことああるので，Cを小さくし位置のみ を合せて次ステップに進む処理を加えた．乙の処理の 効果が Fig. 6 (b)の 80〜90ステップで見られる. Fig. 6(c) 飞よれば，関節の可動範囲の制限が満たさ れているどとあわかる.

\section{6. あとがき}

本論文で述べた主な内容を，今後検討すべき問題点 ととあに，項目別に挙げる.

（1）接触検出法の提案 得られた検出法では, 干 渉があるための必要条件を用いる. このため, 接触の 可能性のあるリンクと障害物との対応が容易に見い出 せる. 接触点を見い出すためにリンクの外側に付加さ れる領域の大きさ，ブロック分割の方法などは，適用 される問題に応じて検討する必要がある.

（2）問題の定式化 1 章で述べた二つの前提のむ とに，できるだけ一般的に定式化した。ただし，一 般には，障害物を除いたマニピュレータの作業域は， 凸領域ではないから，接触によって課せられる条件 (15)は，実際の可動条件よりむ厳しい.

（3）解法の提案 定式化された問題の一つの解法 を提案した，接触がある場合には，(2)で述べたよう に，実際より厳しい条件で解を求めることになるか ら，解が見落される可能性がある，乙の点については 現在検討中である。

（4）平面運動への適用，理解しやすい平面運動に 本方法を適用し, その有効性を確認した.

ここで述べられた方法は, 多自由度多リンクのマニ ピュレータが, 障害物の入り組んだ複雑な作業環境下 で動くときに考えなければならない障害物回避の問題 を，一般的に取り扱うことができる．したがって，今 後, 環境の記述の研究と相まって, 複雑な作業域で用 
いられる工業用ロボットの動作決定の自動化や，多関 節をむつ移動ロボットの自立走行の問題に利用できる と考える.

\section{参 考 文 献}

1) A. M. Thompson: The Navigation System of the JPL Robot, 5th Int. Joint Conf. on Artificial Intelligence, 749/757 (1977)

2) 長谷川：ロボットの作業環境のモデリングとモニタリン グ，計測自動制御学会論文集，17-5，61/67 (1981)

3) L. A. Loeff and A.H. Soni: An Algorithm for Computer Guidance of a Manipulator in Between Obstacles, Trans. of ASME, Journal of Engineering for Industry, 97-3; 836/842 (1975)

4) O. Khatib and J.F. Le Maitre: Dynamic Control of Manipulators Operating in a Complex Environment, On Theory and Practice of Robots and Manipulators, 3rd CISM-IFToMM Symposium, $267 / 282(1978)$

5) 花房，吉川，中村 : 圥長性を有する多関節形ロボットの 制御一I，第 22 回自動制御連合講演会, 321/322 (1979)

6) F.M. Kulakov: Organization of Supervisory
Control of Robots-Manipulators. II, Engineering Cybernetics, 14-6, 59/70 (1976)

7）工藤, 高田, 佐々木：人工の手の径路決定のためのアル ゴリズム，計測自動制御学会論文集，11-4，405/410 (1975)

8) S. M. Udupa: Collision Detection and Avoidance in Computer Controlled Manipulators, 5 th Int. Joint Conf. on Artificial Intelligence, 737/748 (1977)

9) T. Lozano-Pérez: Automatic Planning of Manipulator Transfer Movements, IEEE Trans. on Systems, Man, and Cybernetics, SMC-11-10, 681/ 698 (1981)

10) T. Lozano-Pérez and M. A. Wesley: An Algorithm for Planning Collision-Free Paths Among Polyhedral Obstacles, Commun. ACM, 22-10, 560/570 (1979)

11) J. W. Boyse: Interference Detection Among Solids and Surfaces, Commun. ACM, 22-1, 3/9 (1979)

12) J. Denavit and R.S. Hartenberg: A Kinematic Notation for Lower-Pair Mechnnisms Based on Matrices, Trans. of ASME, Journal of Applied Mechanics, 22-2, 215/221 (1955) 